\title{
NONLINEAR RELATIONSHIPS AND VOLATILITY SPILLOVERS AMONG HOUSE PRICES, INTEREST RATES AND STOCK MARKET PRICES
}

\author{
Hsiang-Hsi LIU a, Sheng-Hung CHEN b,* \\ ${ }^{a}$ Graduate Institute of International Business, National Taipei University, 151, University Rd., San \\ Shia District, New Taipei City, 23741, Taiwan \\ ${ }^{b}$ Department of Finance, Nanhua University, 55, Sec. 1, Nanhua Rd., Zhongkeng, Dalin, Chiayi 62248, \\ Taiwan
}

Received 6 August 2014; accepted 23 October 2015

\begin{abstract}
This paper addresses the interaction between interest rates and the significant increases in both Taiwanese house and stock market prices seen in recent years. Changes in house prices impact banks' nonperforming loans, whereas changes in interest rates directly influence the ability of individuals and businesses to pay loan interest, accentuating the co-movements between house and stock market prices. We investigate the nonlinear relations and volatility spillovers among house prices, interest rates and stock market prices using monthly data from January 1985 to March 2009 for Taiwan. We find that the Smooth Transition Vector Error Correction GARCH (STVEC-GARCH) model has the best forecasting ability based on goodness of fit tests while showing a nonlinear and co-integrated relation among the three variables. Specifically, house price leads stock market returns when the interest rate is led by either house price or stock market returns. The volatility of stock market returns has significant impacts on interest rates, implying that borrowers should be aware of stock market fluctuations and thus strengthen their risk management because of unexpected changes.
\end{abstract}

KEYWORDS: Nonlinear relationship; Smooth Transition Vector Error Correction GARCH Model (STVEC-GARCH); Volatility spillovers; House prices; Interest rates; Stock market returns

\section{INTRODUCTION}

This paper emphasizes the important observation that significant increases in recent house prices and stock market price returns in Taiwan lead to interactive effects among house prices, interest rates, and stock market prices. It is obvious that changes in house prices have substantial influences on banks' nonperforming loans, whereas changes in interest rates also influence the ability of individuals and businesses to repay the loan interest. This, in turn, promotes the co-movements between house prices and stock market returns. Applying the Smooth Transition Vector Error Correction GARCH Model (STVEC-GARCH), we empirically explore the nonlinear interrelations and volatility spillovers among house prices, interest rates, and stock market returns in Taiwan using monthly data from January 1985 to March 2009.

In 1986, Cathay Life Insurance in Taiwan auctioned a number of properties from the National

\footnotetext{
* Corresponding author. E-mail: shenghong@mail.nhu.edu.tw
}

Property Administration of the Ministry of Finance. This event boosted the boom in real estate and caused increased wealth in both enterprises and individuals. Because the market exhibited high profitability, enterprises and individuals could obtain funds from bank loans to further reinvest in real estate and the stock market; this, in turn, resulted in a large and simultaneous expansion of their assets and liabilities. In 1989, Taiwan Central Bank implemented 228 selective credit controls and tightened the reserves to suppress these hot real estate and stock markets. Although the Taiwan stock market index attained an historical high, the real estate market returned to its former level. However, the economic bubble continues to drive declines in real estate and stock market prices. As shown in Figure 1, foreign investment in Taiwan by foreign institutions reached a peak in 2007, despite significant decreases during the global financial crisis (2007-2009). In addition, the loan rate has experienced significant decreases since 1990. Moreover, Figure 2 indicates Taiwanese stock mar- 


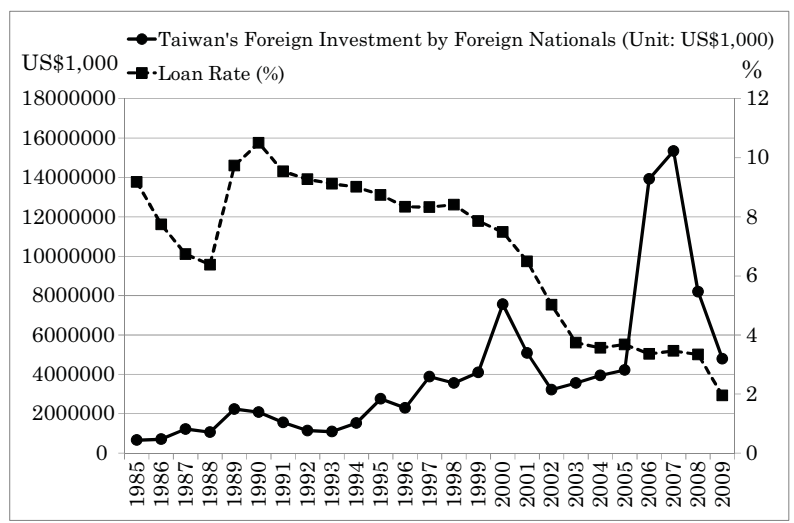

Fig. 1. Taiwan's foreign investment by foreign nationals (unit: US\$1,000) and loan rate (\%) from 1985-2009

Data: Taiwan Investment Commission (MOEA) (www.moeaic.gov.tw) and TEJ

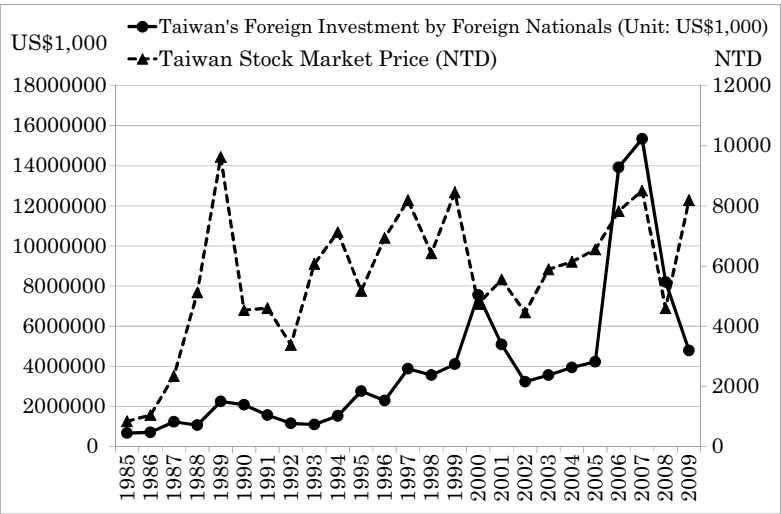

Fig. 2. Taiwan's foreign investment by foreign nationals (unit: US\$1,000) and Taiwan stock market price (NTD) from 1985-2009

Data: Taiwan Investment Commission (MOEA) (www.moeaic.gov.tw) and TEJ

ket prices clearly fluctuated by approximately NTD 7,000 between 1993 and 2000 .

Banks mainly provide financing by using real estate as collateral when house prices increase. When stock price returns and house prices decrease, this effect not only leads to an undervaluation of loan collateral but also shrinks individuals' wealth and income. Hence, individuals fail to repay loans, which results in a sudden increase in nonperforming loans. This result further affects a bank's operation and dramatically changes the interest rate spread between deposits and loans. Based on the above perspective, an interrelation among house prices, interest rates and stock prices exists. This study empirically explores volatility dynamics and spillover among house prices, stock prices and interest rates. We address essential issues regarding substantial increases in both house prices and stock prices, which generates interac- tive effects among house prices, interest rates, and stock market returns. Changes in house prices have incremental impacts on banks' nonperforming loans; changes in interest rates also influence the ability of individuals and businesses to repay loan interest, which, in turn, elevates the co-movements between house prices and stock market prices.

Regarding the related literature on this issue, Chen et al. (2010) indicated that the response of durable consumption to real house prices in Taiwan is statistically significant in a collateral constrained regime. In the UK, Attanasio et al. (2011) found that house price shocks should have a larger effect on the consumption of older households and that earnings shocks should also have a larger effect on young households. Moreover, Hirata et al. (2013) examined house price fluctuations across eighteen advanced economies over the past forty years, and found that house prices are synchronized across countries and that the degree of synchronization has increased over time. Specifically, global interest rate shocks tend to have a significant negative effect on global house prices, whereas global monetary policy shocks per se do not appear to have a sizeable impact. Uncertainty shocks appear to be important in explaining fluctuations in global house prices. Hui and Chan (2013) applied the Forbes-Rigobon multivariate (FRM) test to investigate contagion across equity and real estate markets in four different places - Greece, the U.K., the U.S. and Hong Kong - during the European sovereign debt crisis, and compare the result with those obtained by performing the FRM test directly. It was found that significant contagion existed and that the contagion pattern in the equity and real estate markets are different. This implies that investors should regularly review their portfolio and be aware of contagion triggered by a crisis to help them reduce their loss and to improve their strategic property management. Recently, Louis and Sun (2013) examined the cross-regional link between the growth rate in local housing prices and future long-term abnormal stock returns of local firms during the 1979-2002 period in the USA. The researchers presented reliable evidence that firms' long-term abnormal stock returns are negatively related to past growth in housing prices in the states where the firms are located.

However, the empirical interrelation among house prices, stock market prices and interest rates are noted and investigated less in previous studies. Schwert (1989) used vector auto-regression (VAR) and multi-regression to investigate the volatility 
relation between stock price returns and macroeconomic variables. This researcher found that there was a positive relation between the volatility in the money supply and the volatility in stock price returns. Fu et al. (1993) performed a Granger test on average house prices and the Hen-Sheng stock price index from 1984 to 1993 . The researchers' empirical results indicated that stock prices with one period lag had a positive effect on house prices. Related work by Chirinko et al. (2004) explored the interrelation between stock prices, house prices, and real activity in a 13-country sample. In addition, Dees et al. (2005) investigated the role of monetary, oil and real equity shocks across countries using a global-VAR (GVAR) model including a factor structure to model linkages across countries. Case et al. (2000) examined the dynamics of international commercial real estate markets from 1987-1997. The researchers concluded that comovements among commercial real estate markets occurred through GDP linkages and that commercial real estate is a bet on a country's productivity. Dolde and Tirtiroglu (2002) modeled the volatility of housing price changes and identified 12 significant volatility increases and 24 significant decreases in monthly changes in four regional U.S. house price indexes between 1975 and 1993. The researchers found a significant interregional diffusion of volatility increases and indicated links between economic conditions and housing volatility and returns to be of value to household and mortgage investors. Recently, Hoesli and Reka (2015) investigated the dynamics of financial contagion within a cross asset framework using the interdependences between the U.S. REIT and equity markets. The researchers confirmed that contagion prevails between REITs and stocks and that this phenomenon is driven by behavioral and liquidity mechanisms.

Using impulse responses from the Structural Vector Auto-regression (SVAR) model, Musso et al. (2011) suggested that the impact of monetary policy, credit supply and housing demand shocks is qualitatively similar in the US and the euro area. At the same time, the researchers find that the transmission of monetary policy shocks to the housing market is stronger in the US than in the euro area. This implies that housing markets may play a larger role as conduits of monetary policy shocks in the US than in the euro area, whereas the evidence for housing demand and credit supply shocks is less clear. Regarding monetary policy shocks, Jarocinski and Smets (2008) and Goodhart and Hofmann (2008) performed similar analyses for the US and a panel of industrialized countries, respectively. Iacoviello (2005), Iacoviello and Neri (2010), and Calza et al. (2013) suggested that the bulk of the effect of changes in house prices in the macro economy occurs through a collateral mechanism because credit-constrained households are allowed to borrow solely against housing equity. Previous research showed that residential investment is a leading indicator of, and an important contributor to the business cycle (Leamer 2007) and that fluctuations in house prices have significant wealth effects on consumption (Case et al. 2005). Pavlidis et al. (2009) found that house prices have a wealth effect on consumption solely for fluctuations in housing values that are caused by bubbles. Ghent and Owyang (2010) found that the positive relation between housing and overall activity does not hold for cross-sections at US. Metropolitan areas level; this is puzzling because housing shocks are, to a large extent, local.

Furthermore, co-integration is frequently utilized to analyze the long run equilibrium among different variables. This method examines not only long run equilibrium using the Vector ErrorCorrection Model (VECM) but also the short run dynamic adjustment (Engle, Granger 1987; Engle 1982). However, stock prices adjusted smoothly when the impact of a specific event exceeded the price limit in the stock market. Using Hong Kong annual data for the 1974-1998 periods, Tse (2001) indicated that the impact of residential property prices on common stock prices was more than 127 percent of the impact of office prices on stock prices, whereas changes in stock prices tended to move with residential and office property prices in the long run. The author also suggested that, although changes in expectations are an important determinant of the short run correlation between property and stock prices, the long-run positive correlation is due to economic fundamentals that affect both property and stock prices. Furthermore, Sing and Tan (2013) used the DCC-GARCH model to test the time-varying correlations between stock and direct real estate returns in six markets including the USA, the UK, Ireland, Australia, Hong Kong and Singapore. The researchers showed significant time-varying effects in the conditional covariance between stock returns and direct real estate returns; this indicated that the conditional covariance increases in the boom markets, but becomes weaker in the post-crisis periods.

Based on this perspective, the present study applies STVECM-GARCH to model the smooth adjustment and to capture the threshold effect 
among stock prices, house prices and interest rates in the presence of extreme event occurrences. Specifically, we use the transition function to properly identify and capture nonlinear processing in different states among these three variables. We also model the GARCH effect to measure the threshold effect and volatility spillovers in co-movements among the three variables noted above (Bollerslev 1986; Bollerslev et al. 1992, 1998). Our empirical results provide great help to investors and policy makers in real estate, stock market, and government agencies as a policy reference.

\section{SMOOTH TRANSITION VECTOR ERROR CORRECTION GARCH MODEL (STVEC- GARCH)}

To quantify the smooth adjustment and threshold effect among stock prices, house prices, and interest rates in the presence of an event occurrence, STVECM-GARCH is properly applied to our empirical estimation. If a time series exists in co-integration, it has a corresponding VEC model. Prior establishing the STVEC model, the first step is to build a VEC model, the second step is to test the linearity, and the final step is to select the model (Rothman et al. 2001).

\subsection{VECM}

First, we establish a VECM to model the interrelations among stock price, house price, and interest rate as follows:

$$
\begin{aligned}
\Delta H_{t}= & a_{0}+a_{1} Z_{t-1}+\sum_{i=1}^{p} a_{i+1}\left(\Delta H_{t-i}\right)+ \\
& \sum_{i=1}^{p} a_{i+1+p}\left(\Delta S_{t-i}\right)+\sum_{i=1}^{p} a_{i+1+2 p}\left(\Delta R_{t-i}\right)+\varepsilon_{h t} ; \\
\Delta S_{t}= & b_{0}+b_{1} Z_{t-1}+\sum_{i=1}^{p} b_{i+1}\left(\Delta H_{t-i}\right)+ \\
& \sum_{i=1}^{p} b_{i+1+p}\left(\Delta S_{t-i}\right)+\sum_{i=1}^{p} b_{i+1+2 p}\left(\Delta R_{t-i}\right)+\varepsilon_{h t} \\
\Delta R_{t}= & c_{0}+c_{1} Z_{t-1}+\sum_{i=1}^{p} c_{i+1}\left(\Delta H_{t-i}\right)+ \\
& \sum_{i=1}^{p} c_{i+1+p}\left(\Delta S_{t-i}\right)+\sum_{i=1}^{p} c_{i+1+2 p}\left(\Delta R_{t-i}\right)+\varepsilon_{h t}
\end{aligned},
$$

where: $\Delta H_{t}, \Delta S_{t}$ and $\Delta R_{t}$ represent changes in house price, stock price, and interest rate between $t$ and $t$-1, namely. $Z_{t-1}=H_{t-1}-c_{0}-S_{t-1}-R_{t-1}$, are defined as the error correction term among house price, stock price, and interest rate at lagged periods of one month. Moreover, $a_{1}, b_{1}$, and $c_{1}$ are adjusted coefficients that measure the necessary time it takes for deviation in co-integration to return to equilibrium among the three variables. Finally, $a_{0}, b_{0}$ and $c_{0}$ are all constant terms.

\subsection{Nonlinear test and model selection}

Granger and Swanson (1996), Chan and McAleer (2003), as well as McMillan (2005) augmented a smooth transition function by incorporating it into a VECM to extend STVECM. This paper also considers GARCH effects, which are included in the volatility equation for house prices, stock prices, and interest rates. We estimate the following STVEC-GARCH model. All parameters and variables used in the model are defined as:

$$
\begin{aligned}
\Delta H_{t}= & a_{0}+a_{1} Z_{t-1}+a_{2} \sum \Delta H_{t-i}+a_{3} \sum \Delta S_{t-i}+ \\
& a_{4} \sum \Delta R_{t-i}+\left(a_{5}+a_{6} Z_{t-1}+a_{7} \sum \Delta H_{t-i}+;\right. \\
& \left.a_{8} \sum \Delta S_{t-i}+a_{9} \sum \Delta R_{t-i}\right) \times F_{L}\left(Z_{t-d} \mid \gamma_{h}, c_{h}\right)+\varepsilon_{h t}
\end{aligned}
$$

$$
\begin{aligned}
\Delta S t= & b_{0}+b_{1} Z_{t-1}+b_{2} \sum \Delta H_{t-i}+b_{3} \sum \Delta S_{t-i}+ \\
& b_{4} \sum \Delta R_{t-i}+\left(b_{5}+b_{6} Z_{t-1}+b_{7} \sum \Delta H_{t-i}+\right. \\
& \left.b_{8} \sum \Delta S_{t-i}+b_{9} \sum \Delta R_{t-i}\right) \times F_{E}\left(Z_{t-d} \mid \gamma_{s}, c_{s}\right)+\varepsilon_{s t} \\
\Delta R t= & c_{0}+c_{1} Z_{t-1}+c_{2} \sum \Delta H_{t-i}+c_{3} \sum \Delta S_{t-i}+ \\
& c_{4} \sum \Delta R_{t-i}+\left(c_{5}+c_{6} Z_{t-1}+c_{7} \sum \Delta H_{t-i}+\right. \\
& \left.c_{8} \sum \Delta S_{t-i}+c_{9} \sum \Delta R_{t-i}\right) \times F_{L}\left(Z_{t-d} \mid \gamma_{r}, c_{r}\right)+\varepsilon_{r t}
\end{aligned}
$$

$$
\begin{aligned}
& h_{h, t}=c_{11}+a_{11} \varepsilon_{h, t-1}^{2}+b_{11} h_{h, t-1}+f_{1} h_{s, t-1}+f_{2} h_{r, t-1} \\
& h_{s, t}=c_{22}+a_{22} \varepsilon_{s, t-1}^{2}+b_{22} h_{s, t-1}+f_{3} h_{h, t-1}+f_{4} h_{r, t-1} \\
& h_{r, t}=c_{33}+a_{33} \varepsilon_{r, t-1}^{2}+b_{33} h_{s, t-1}+f_{5} h_{h, t-1}+f_{6} h_{s, t-1} \\
& \varepsilon t=\left|\begin{array}{lll}
\varepsilon h t & \varepsilon s t & \varepsilon r t
\end{array}\right| \sim N(0, H t)
\end{aligned}
$$




$$
H_{t}=\left[\begin{array}{lll}
h h h & h h s & h h r \\
h_{s h} & h_{s s} & h_{s r} \\
h r h & h_{r s} & h_{r r}
\end{array}\right],
$$

where: $\Delta H_{t}$ : changes in house prices at time $t$; $\Delta S_{t}$ : returns on stock market prices at time $t$; $\Delta R_{t}$ : changes in interest rates at time $t ; \varepsilon_{h t}:$ error term of house prices at time $t ; \varepsilon_{s t}$ : error term of stock price returns at time $t ; \varepsilon_{r t}$ : error term of changes in interest rates at time $t ; h_{h, t}$ : conditional variance of house prices at time $t ; h_{s, t}$ : conditional variance of stock price return at time $t ; h_{r, t}$ : conditional variance of changes in interest rates at time $t ; f_{1}$ : spillover effects of stock price returns on house price returns at time $t ; f_{2}$ : spillover effect of changes in interest rates on house price returns at time $t ; f_{3}$ : volatility spillover effect of house price returns on stock price returns at time $t ; f_{4}$ : volatility spillover effect of changes in interest rates on stock price returns at time $t ; f_{5}$ : volatility spillover effect of house price returns on changes in interest rates at time $t ; f_{6}$ : volatility spillover effect of changes in interest rates on changes in interest rates at time $t ; F\left(Z_{t-d} \mid \gamma, c\right)$ is a transition function. According to the setting established by Terasvirta (1994), the transition function follows two types of distributions: exponential and logistic. Hence, the transition functions can be expressed as follows:

$$
\begin{aligned}
& F_{E}\left(z_{t-d}\right)=1-\exp \left\{-\gamma(z t-d-c)^{2}\right\} ; \\
& F_{L}\left(z_{t-d}\right)=[1+\exp \{-\gamma(z t-d-c)\}]^{-1},
\end{aligned}
$$

where: $Z_{t-d}$ is a transition variable; $d$ is the lag period, and $\gamma$ is a smooth parameter indicating the transition speed between two variables. This suggests that the higher $\gamma$ is, the faster the speed of adjustment is, and $c$ is the threshold value between two different states. Based on the definition of two types of transition functions, STVECM can be classified using two types: (1) The exponential form, LSTVECM (logistic smooth transition vector error correction model) with the same dynamic structure using an exponential function form if $Z_{t-d}>c$ and $Z_{t-d}<c$; and (2) the logistic form, ESTVECM (exponential smooth transition vector error correction model) with the differential dynamic structure using a logistic function form if $Z_{t-d}>c$ and $Z_{t-d}<c$.

Prior to the estimation of STVECM, we must examine whether our data possess nonlinear characteristics. We then test the following hypotheses:

$$
\begin{aligned}
& H_{0}: \gamma=0(\text { VECM }) \\
& H_{1}: \gamma>0(\text { STVECM })
\end{aligned}
$$

Because the transition function converges to zero or a constant while $\gamma$ approaches zero. The hypothesis contains the following condition:

$$
\begin{aligned}
& \lim _{\gamma \rightarrow 0} F\left(Z_{t-d} \mid \gamma, c\right)=0 ; \\
& \lim _{\gamma \rightarrow 0} F\left(Z_{t-d} \mid \gamma, c\right)=\frac{1}{2} .
\end{aligned}
$$

The STVECM transforms the following structure when satisfying the condition above.

$$
\begin{aligned}
\Delta H_{t}= & a_{0}+a_{1} Z_{t-1}+\sum_{i=1}^{p} a_{i+1}\left(\Delta H_{t-i}\right)+ \\
& \sum_{i=1}^{p} a_{i+1+p}\left(\Delta S_{t-i}\right)+\sum_{i=1}^{p} a_{i+1+2 p}(\Delta R t-i)+\varepsilon h t
\end{aligned} ;
$$

$$
\begin{aligned}
\Delta H_{t}= & a_{0}+a_{1} Z_{t-1}+a_{2} \sum \Delta H_{t-i}+a_{3} \sum \Delta S_{t-i}+ \\
& a_{4} \sum \Delta R_{t-i}+\left(a_{5}+a_{6} Z_{t-1}+a_{7} \sum \Delta H_{t-i}+\right. \\
& \left.a_{8} \sum \Delta S_{t-i}+a_{9} \sum \Delta R_{t-i}\right) \times \frac{1}{2}+\varepsilon_{h t}
\end{aligned}
$$

Either Equation (17) or (18) is a linear model. ESTVECM frequently fails to identify the coefficients of $a_{5}, a_{6}, a_{7}, a_{8}, a_{9}$, and $c$ if $\gamma=0$. This means those coefficients would fit any value. Therefore, Luukkonen et al. (1988) used three moments of the Taylor expansion to develop $F\left(Z_{t-d} \mid \gamma, c\right)$ while $\gamma=0$ as follows:

$$
\begin{aligned}
\Delta H_{t}= & \beta_{10}+\beta_{11}{ }^{\prime} W_{t}+\beta_{12}{ }^{\prime} W_{t} Z_{t-d}+ \\
& \beta_{13} W_{t} Z^{2} t-d+\beta_{14}{ }^{\prime} W_{t} Z^{3} t-d+v h t,
\end{aligned}
$$

where: $W_{t}=\left(Z_{t-1}, \Delta H_{t-1}, \cdots, \Delta H_{t}-p, \Delta S_{t-1}, \cdots\right.$,

$$
\Delta S_{t-p}, \Delta R_{\left.t-1, \cdots, \Delta R_{t}-p\right) .}
$$

We can test the following linear test under different lag $d$ :

$$
H_{0}: \quad \beta_{12}^{\prime}=\beta_{13}^{\prime}=\beta_{14^{\prime}}=0 .
$$

We apply the following $F$ statistics to examine the linearity:

$$
F=\frac{\left(S S R_{0}-S S R_{1}\right) / 3 p}{S S R_{1} /(N-4 p-1)} \sim F(3 p, T-4 p-1),
$$

where: $S S R_{0}$ is the sum of squared errors for regression using Equation (1), and $S S R_{d}$ is the sum of square errors for regression using Equation (3) where $N$ is the sample size; $p$ is the lag period, the degree of freedom in $\mathrm{F}$ statistics is $3 p$ and $N-4 p-1$, respectively. We select a different $d$ to test linearity. The criterion of section tends to select the minimum value of $F$ statistics or the $p$-value. 


\subsection{Model selection for LSTVECM and ESTVECM}

After verifying the nonlinearity in STVECM, we use the following hypotheses to test LSTVECM and ESTVECM according to different transition functions:

$$
\begin{aligned}
& H_{04}: \beta_{14}=0 ; \\
& H_{03}: \beta_{13}=0 \mid \quad \beta 14=0 ; \\
& H_{02}: \beta_{12}=0 \mid \quad \beta 13=\beta_{14}=0 .
\end{aligned}
$$

The criteria of testing states are as follows:

(1) When we reject $H_{04}$, the model is LSTVECM.

(2) When we accept $H_{04}$ but reject $H_{03}$, the model is ESTVECM.

(3) When we accept $H_{04}$ and $H_{03}$ but reject $H_{02}$, the model is LSTVECM.

\section{DATA AND EMPIRICAL RESULTS}

\subsection{Data description}

This paper uses monthly data on stock prices, house prices, and interest rates in Taiwan from January 1985 to December 2009. Our final samples for empirical estimation are 288 observations. Data on stock price $(S)$ is defined as a valueweighted index from the Taiwan Stock Exchange market. House price $(H)$ is defined as the monthly average price of a predicted presale in Taipei city. Interest rate $(R)$ data are collected from the Taiwan Central Bank.
Table 1 shows basic statistics and reports the estimated results of the normality test on level data for stock prices, house prices, and interest rates. First, the logarithm of house prices is highly skewed and also displays excess kurtosis, indicating a greater chance of experiencing extreme and negative returns. Additionally, the logarithm of stock prices and interest rates are similar to this finding. In addition to the stock price level, none of the series are actually normally distributed based on the Jarque-Bera tests for normality, although they are skewed or have excess kurtosis as well. This, by itself, provides an indication that the most heavily affected market was that of specific events. Hence, we then quantify the volatility clustering using the GARCH model. In addition, the $Q$ test result confirms that all series reject the hypothesis of white noise, suggesting we must verify whether all series are stationary prior to empirical estimation.

\subsection{Unit root test}

According to the results in Table 2 of the ADF test (Dickey, Fuller 1979, 1981) for the unit root on the three time series, all three variables (logarithm of stock price, interest rates, and house prices) are shown to be non-stationary with the intercept and with the time trend. However, as shown in Table 3, after first differencing, all series significantly reject the hypothesis with unit root I (1), suggesting all series are stationary; in addition, there may be a co-integrating relation among stock

\begin{tabular}{|c|c|c|c|c|c|c|}
\hline \multirow[t]{2}{*}{ Statistics } & \multicolumn{3}{|l|}{ Level } & \multicolumn{3}{|l|}{ Log } \\
\hline & $\begin{array}{l}\text { House prices } \\
(\mathrm{H})\end{array}$ & Stock prices (S) & $\begin{array}{l}\text { Interest rates } \\
\text { (R) }\end{array}$ & Stock prices (S) & $\begin{array}{l}\text { House prices } \\
(\mathrm{H})\end{array}$ & $\begin{array}{l}\text { Interest rates } \\
\text { (R) }\end{array}$ \\
\hline Mean & 28.314 & $6,831.291$ & 6.124 & 8.141 & 3.114 & 0.956 \\
\hline $\begin{array}{l}\text { Standard De- } \\
\text { viation }\end{array}$ & 7.314 & $2,631.414$ & 2.014 & 0.692 & 0.402 & 0.314 \\
\hline Minimum & 6.360 & 882.950 & 2.821 & 6.831 & 1.923 & 1.316 \\
\hline Maximum & 33.640 & $12,054.350$ & 10.501 & 9.581 & 3.624 & 2.514 \\
\hline Skewness & -1.245 & -0.113 & -0.612 & -1.078 & -2.841 & -1.124 \\
\hline Kurtosis & 4.621 & 3.524 & 2.824 & 3.821 & 7.418 & 3.014 \\
\hline JB Statistics & $121.376^{* * *}$ & 1.604 & $16.412^{* * *}$ & $25.316^{* * *}$ & $438.207^{* * *}$ & $52.240^{* * *}$ \\
\hline $\mathrm{Q}(12)$ & $1,894.601^{* * *}$ & $1,314.225^{* * *}$ & $2,157.215^{* * *}$ & $1,512.316^{* * *}$ & $1,966.912^{* * *}$ & $3,245.154^{* * *}$ \\
\hline $\mathrm{Q}(24)$ & $2,314.315^{* * *}$ & $1,412.512^{* * *}$ & $2,712.165^{* * *}$ & $1,601.312^{* * *}$ & $2,312.512^{* * *}$ & $2,712.212^{* * *}$ \\
\hline
\end{tabular}
prices, interest rate, and house prices.

Table 1. Descriptive statistics

Note: Author's calculation; * **, *** statistically significant at level of $10 \%, 5 \%$, and $1 \%$, respectively. 
Table 2. ADF unit root test on house price, stock price, and interest rate

\begin{tabular}{llll}
\hline ADF Statistics & & & \\
\hline Variables & $\begin{array}{l}\text { With constant } \\
\text { and time trend }\end{array}$ & $\begin{array}{l}\text { With constant, } \\
\text { without time trend }\end{array}$ & $\begin{array}{l}\text { Without constant } \\
\text { and time trend }\end{array}$ \\
\hline House price & -2.915 & -3.518 & 1.034 \\
Stock price & -3.014 & -3.336 & 0.931 \\
Interest rate & -1.615 & -0.541 & -0.891 \\
\hline
\end{tabular}

Note: Author's calculation; *, **, *** statistically significant at level of $10 \%, 5 \%$, and $1 \%$, respectively.

Table 3. ADF unit root test on first differencing in house price, stock price, and interest rate

\begin{tabular}{llll}
\hline ADF Statistics & & & \\
\hline Variables & $\begin{array}{l}\text { With constant } \\
\text { and time trend }\end{array}$ & $\begin{array}{l}\text { With constant, } \\
\text { without time trend }\end{array}$ & $\begin{array}{l}\text { Without constant } \\
\text { and time trend }\end{array}$ \\
\hline$\Delta$ House price & $-10.110^{* * *}$ & $-9.961^{* * *}$ & $-4.441^{* * *}$ \\
$\Delta$ Stock price & $-13.214^{* * *}$ & $-12.916^{* * *}$ & $-13.812^{* * *}$ \\
$\Delta$ Interest rate & $-14.101^{* * *}$ & $-12.217^{* * *}$ & $-13.910^{* * *}$ \\
\hline
\end{tabular}

Note: Author's calculation; ***, *** statistically significant at level of $10 \%, 5 \%$, and $1 \%$, respectively. $\Delta$ indicated first differencing in the variable.

\subsection{Johansen co-integration test}

Based on the results of Table 4, a long-term co-integrating relation exists among house price, stock market prices and interest rate after first differencing. In other words, a linear transition from all series can be transformed into a new stationary series via a linear combination with different series (Johansen 1988; Johansen, Juselius 1990). It is shown that we accept the hypothesis with at least one co-integration vector at the $5 \%$ level. The co-integration equation $Z_{t-1}$ is shown as follows:

$$
\begin{array}{r}
Z_{t-1}=H_{t-1}-0.614 S_{t-1}+0.127 R_{t-1}+1.821 \\
(2.14)^{* *}(2.36)^{* *}(2.56)^{* *} .
\end{array}
$$

There is a co-integrating effect of house prices, stock market prices and interest rates, suggesting that there are no significant changes in these series in the short-term, and the long-term trend as a result of the effect from other stock markets leads to co-movement among stock prices, interest rates and house prices. This phenomenon indicates that investors can predict the stock and house prices in long run equilibrium. Therefore, we establish a vector error correction model to consider long-term information using $Z_{t-1}$ for individual variables.

\subsection{Nonlinear test and model selection}

Prior to specifying and estimating STVECM, we must verify whether the series of house prices, stock market prices and interest rates are stationary. The results of the unit root test in Table 3 indicate that all series are stationary after first differencing. Based on Granger and Terasvirta (1993), we first conduct the nonlinear test and then perform the model section and estimation. As Table 5 demonstrates, the minimum values of AIC and SBC exist when $p=1$ (Akaike 1969). According to these results, we select all variables with 1 lag for our VEC model.

Table 5. Variable section for optimal lag period in VAR model

\begin{tabular}{lll}
\hline Lag & AIC & SBC \\
\hline 1 & $-3.542^{*}$ & $-3.451^{*}$ \\
2 & -3.532 & -3.420 \\
3 & -3.482 & -3.301 \\
4 & -3.468 & -3.261 \\
5 & -3.457 & -3.181 \\
6 & -3.381 & -2.162 \\
7 & -3.371 & -3.142 \\
8 & -3.362 & -3.096
\end{tabular}

Note: Author's calculation; $* * *, * * *$ statistically significant at level of $10 \%, 5 \%$, and $1 \%$, respectively.

Table 4. Johansen cointeragtion vector and trace test

\begin{tabular}{lllll}
\hline $\begin{array}{l}\text { Number of cointegra- } \\
\text { tion Vector }\left(H_{0}\right)\end{array}$ & Eigenvalue & Trace statistics & $\begin{array}{l}5 \% \\
\text { Critical value }\end{array}$ & $\begin{array}{l}1 \% \\
\text { Critical value }\end{array}$ \\
\hline None & 0.0912 & $42.916^{* * *}$ & 28.312 & 34.812 \\
At least one & 0.0614 & $16.912^{* *}$ & 15.010 & 18.212 \\
At least two & 0.00303 & 0.791 & 3.621 & 6.421 \\
\hline
\end{tabular}

Note: Author's calculation; * **, *** statistically significant at level of $10 \%, 5 \%$, and $1 \%$, respectively. 
The LM linear test statistic is used to examine the nonlinearity in house price, stock market prices and the interest rate by selecting the optimal $d$. Table 6 reports results of different statistics using lag 1 to 4 and $d$. If the $P$-value is less than $10 \%, 5 \%$, and $1 \%$, the series exhibits the STVEC model trend. Hence, we select d to satisfy the $P$ value minimum to reject the null hypothesis. We use $d$ as the optimal lag period for a series in the STVEC model. As shown in Table 6, we obtain the $P$-value minimum when $d$ equals 1 for a series of stock prices and interest rates. We select $d=1$ as the lag variable in $Z_{t-d}$ while choosing $d=1$ as the lag variable in $Z_{t-d}$.

Table 6. Linear test and section $d$

\begin{tabular}{lllll}
\hline Series & $\begin{array}{l}\text { Delay } \\
\text { period } \\
(d)\end{array}$ & $\begin{array}{l}\text { Lag } \\
\text { period } \\
(p)\end{array}$ & $F$-Statistics & $P$-Value \\
& 1 & 1 & $2.141^{\#}$ & $0.0138^{* *}$ \\
\hline House price & 1 & 1 & 0.981 & 0.462 \\
& 2 & 1 & 1.102 & 0.431 \\
& 3 & 1 & 1.342 & 0.582 \\
Stock price & 1 & 1 & 3.415 & $0.0002^{* * *}$ \\
& 2 & 1 & $3.608^{\#}$ & $0.0001^{* * *}$ \\
& 3 & 1 & 2.671 & $0.0060^{* * *}$ \\
Interest & 1 & 1 & 1.872 & 0.0321 \\
rate & & 1 & $4.33^{\#}$ & $0.0000^{* * *}$ \\
& 2 & 1 & 3.948 & $0.0000^{* * * *}$ \\
& 3 & 1 & 2.542 & $0.0046^{* * *}$ \\
& 4 & 1 & 2.802 & $0.0014^{* * *}$ \\
\hline
\end{tabular}

Note: Author's calculation; ${ }^{*}, * *, * * *$ statistically significant at level of $10 \%, 5 \%$, and $1 \%$, respectively. \# indicates the maximum of $F$-Statistics $F$ or the minimum of $P$-Value.

\subsection{Model selection for LSTAR and ESTAR}

Based on the result of Table 7 for the nonlinear test, house prices, stock market prices and interest rates all show a nonlinear trend in the STVEC model. We further select which type of distribution best fits the STVEC model, LSTVEM or ESTVEM. After verifying the trend of the series used in our models, we then proceed with model selection using regression. Based on the $P$-value minimum when rejecting three null hypotheses $\left(H_{04}, H_{03}\right.$, and $H_{02}$ ), we then easily select the fitted STVEC model. We use the following criteria to select the LSTVECM or ESTVECM: (1) LSTVECM is selected as the best model, whereas the $P$-value minimum can be determined in either the first or third testing. (2) ESTVEC is selected as the best model, whereas the $P$-value minimum can be solely determined in second testing. Specifically, Granger and Terasvirta (1993) as well as Terasvirta (1994) also suggested using the $P$-value minimum among three hypotheses as the basis for model selection, which is better than the sequent testing above. Based on these researchers' perspective, this paper uses both sequent testing and the minimum $P$-value to select the best fitted model.

Table 7 reports the estimated results of $L S T$ VECM and ESTVECM, respectively. First, based on the sequent test, the stock price return and change in interest rate follow the LSTVECM trend. However, according to the minimum $P$-value, the stock price returns show the ESTVECM trend, and the stock price returns and change in the interest rate follow the LSTVECM trend, which is the same result as the sequent test. When the series exhibits the ESTVECM trend in Table 7, this implies that the series demonstrates different dynamic trends with transition periods; however, the transition variable has the same trend in a positive or negative state. Similarly, although the series exhibits the LSTVECM trend, this suggests that the series has the same dynamic trends as the transition periods; however, the transition variables have different trends in a positive or negative state.

Table 7. Model section for STAR model

\begin{tabular}{|c|c|c|c|c|c|c|}
\hline Series & Delay period $(d)$ & Lag period $(p)$ & Hypothesis & $F$-Statistics & $P$-Value & Fitted model \\
\hline \multirow[t]{3}{*}{ House price } & 1 & 2 & $H_{04}$ & 3.924 & $0.0045 \#$ & \\
\hline & 1 & 2 & $H_{03}$ & 0.824 & 0.5260 & \\
\hline & 1 & 2 & $H_{04}$ & 1.652 & 0.1420 & LSTVECM \\
\hline \multirow[t]{3}{*}{ Stock price } & 2 & 6 & $H_{04}$ & 1.681 & 0.1410 & \\
\hline & 2 & 6 & $H_{03}$ & 6.281 & $0.0001 \#$ & \\
\hline & 2 & 6 & $H_{04}$ & 1.968 & 0.1082 & ESTVECM \\
\hline \multirow[t]{3}{*}{ Interest rate } & 4 & 2 & $H_{04}$ & 4.926 & $0.0009 \#$ & \\
\hline & 4 & 2 & $H_{03}$ & 3.611 & 0.0076 & LSTVECM \\
\hline & 4 & 2 & $H_{04}$ & 3.996 & 0.0031 & \\
\hline
\end{tabular}

Note: Author's calculation. \# represents the minimum of $P$-Value. 


\subsection{Estimated results of STVECM}

Prior to the estimation of STVECM, Terasvirta and Anderson (1992) and Terasvirta (1994) suggested the standardization of the transition variable in transition function. Using this standardization will help to converge the estimation. Next, we use $Q$ and $Q^{2}$ test by Ljung-Box to examine the presence of the autocorrelation in residuals and the ARCH effect in STVECM.

As shown in Table 8, autocorrelation does not exist in the residuals of the mean equations for house price, stock market prices and interest rate. In addition to the mean equations for house price, the other two variables demonstrate that there are autocorrelations in squared residuals; this suggests that there is volatility clustering in the series in either the stock price or the interest rate. In other words, the stock market prices and the interest rate exhibit heteroscedasticity in their time series. Hence, we include the GARCH model in our STVECM to model volatility clustering in series.

\subsection{Estimated results of STVECM-GARCH}

\section{Mean equation in STVECM-GARCH}

As reported in panel A of Table 9, stock prices are not significantly affected by either house prices or interest rates. The estimated coefficient of smooth transition for house prices is $18.454\left(=\gamma_{h}\right)$, which is smaller than the equivalent values for stock prices and interest rates, implying that in the long run, house prices deviate from the equilibrium with the slowest speed from one transition state to another. According to the estimated coefficient of threshold value, $0.0218\left(=c_{h}\right)$, this indicates that house prices will transit to another state while diverging from the equilibrium by $2.18 \%$ in the long run. Once house price return is transited, the lag effect with a positive value of $0.138\left(=a_{2}\right)$ is changed to a negative effect with a value of -0.334 $\left(=a_{2}+a_{7}\right)$, implying that a positive effect exists in long run equilibrium but a negative effect exists in long run disequilibrium.

Table 8. Estimated result of STVECM: house price, stock price, and interest rate

\begin{tabular}{|c|c|c|c|c|c|c|c|c|}
\hline \multicolumn{3}{|l|}{ House price } & \multicolumn{3}{|l|}{ Stock price } & \multicolumn{3}{|c|}{ Interest rate } \\
\hline \multicolumn{3}{|c|}{ Empirical model: LSTVECM } & \multicolumn{3}{|c|}{ Empirical model: ESTVECM } & \multicolumn{3}{|c|}{ Empirical model: LSTVECM } \\
\hline Parameter & Coefficient & $(t$-statistics) & Parameter & Coefficient & (t-statistics) & Parameter & Coefficient & $(t$-statistics $)$ \\
\hline \multicolumn{9}{|c|}{ Panel A. Mean equation } \\
\hline$a_{0}$ & 0.0132 & $(1.150)$ & $b_{0}$ & -0.0723 & $(-1.176)$ & $c_{0}$ & -0.000781 & $(-0.401)$ \\
\hline$a_{1}$ & -0.0321 & $(-0.741)$ & $b_{1}$ & $0.6981^{* *}$ & $(2.195)$ & $c_{1}$ & -0.00814 & $(-0.802)$ \\
\hline$a_{2}$ & $0.132^{* * *}$ & $(2.376)$ & $b_{2}$ & -0.683 & $(-0.918)$ & $c_{2}$ & 0.0431 & $(1.281)$ \\
\hline$a_{3}$ & -0.0541 & $(-0.841)$ & $b_{3}$ & $0.325^{* * *}$ & $(2.245)$ & $c_{3}$ & 0.0142 & $(0.792)$ \\
\hline$a_{4}$ & 0.141 & $(0.871)$ & $b_{4}$ & 0.881 & $(0.921)$ & $c_{4}$ & $0.121^{* * *}$ & $(2.899)$ \\
\hline$a_{5}$ & -0.0132 & $(-1.090)$ & $b_{5}$ & $0.108^{* *}$ & $(2.163)$ & $c_{5}$ & $-0.821 * * *$ & $(-10.822)$ \\
\hline$a_{6}$ & 0.0461 & $(0.842)$ & $b_{6}$ & $-0.671^{* *}$ & $(-2.025)$ & $c_{6}$ & $0.518^{* * *}$ & $(0.821)$ \\
\hline$a_{7}$ & $-0.4691^{* * *}$ & $(-3.199)$ & $b_{7}$ & 0.662 & $(1.748)$ & $c_{7}$ & $0.713^{* * *}$ & $(14.101)$ \\
\hline$a_{8}$ & 0.0578 & $(0.597)$ & $b_{8}$ & $-0.719 * * *$ & $(-2.312)$ & $c_{8}$ & $0.227 * * *$ & $(5.385)$ \\
\hline$a_{9}$ & -0.6851 & $(-0.151)$ & $b_{9}$ & -0.232 & $(-1.287)$ & $c_{9}$ & -0.803 & $(-1.257)$ \\
\hline$\gamma_{h}$ & $16.0271^{* * *}$ & $(2.652)$ & $\gamma_{s}$ & $126.612^{* * *}$ & $(2.415)$ & $\gamma_{r}$ & $70.541^{* * *}$ & $(3.105)$ \\
\hline$c_{h}$ & $0.0226^{* *}$ & $(2.088)$ & $c_{s}$ & $0.0081^{* * *}$ & $(3.011)$ & $c_{r}$ & $0.334^{* * *}$ & $(2.117)$ \\
\hline \multicolumn{9}{|c|}{ Panel B. Residuals test } \\
\hline$Q(4)$ & 2.505 & & $Q(4)$ & 2.008 & & $Q(4)$ & 8.831 & \\
\hline$Q(8)$ & 6.726 & & $Q(8)$ & 9.383 & & $Q(8)$ & 9.326 & \\
\hline$Q(12)$ & 17.102 & & $Q(12)$ & 14.578 & & $Q(12)$ & 14.118 & \\
\hline$Q(16)$ & 13.118 & & $Q(16)$ & 23.992 & & $Q(16)$ & 24.007 & \\
\hline$Q^{2}(4)$ & 1.824 & & $Q^{2}(4)$ & $64.881^{* * *}$ & & $Q^{2}(4)$ & $15.118^{* * *}$ & \\
\hline$Q^{2}(8)$ & 2.631 & & $Q^{2}(8)$ & $73.671^{* * *}$ & & $Q^{2}(8)$ & $15.832^{* * *}$ & \\
\hline$Q^{2}(12)$ & 3.672 & & $Q^{2}(12)$ & $81.081^{* * *}$ & & $Q^{2}(12)$ & $15.991^{* * *}$ & \\
\hline$Q^{2}(16)$ & 5.296 & & $Q^{2}(16)$ & $86.062 * * *$ & & $Q^{2}(16)$ & $15.998^{* * *}$ & \\
\hline
\end{tabular}

Note: Author's calculation; * **, *** statistically significant at level of $10 \%, 5 \%$, and $1 \%$, respectively. 
Table 9. Estimated result of STVEC-GARCH model: house price, stock price, and interest rate

\begin{tabular}{|c|c|c|c|c|c|c|c|c|}
\hline \multirow{2}{*}{\multicolumn{3}{|c|}{$\begin{array}{l}\text { House price } \\
\text { Empirical model: } L S T V E C M\end{array}$}} & \multicolumn{3}{|l|}{ Stock price } & \multicolumn{3}{|c|}{ Interest rate } \\
\hline & & & \multicolumn{3}{|c|}{ Empirical model: ESTVECM } & \multicolumn{3}{|c|}{ Empirical model: $L S T V E C M$} \\
\hline Parameter & Coefficient & $(t$-statistics $)$ & Parameter & Coefficient & $(t$-statistics) & Parameter & Coefficient & $(t$-statistics $)$ \\
\hline \multicolumn{9}{|c|}{ Panel A. Mean equation } \\
\hline$a_{0}$ & 0.0136 & $(1.152)$ & $b_{0}$ & -0.0731 & $(-1.773)$ & $c_{0}$ & 0.000182 & $(0.126)$ \\
\hline$a_{1}$ & -0.0336 & $(-0.748)$ & $b_{1}$ & $0.734^{* *}$ & $(2.030)$ & $c_{1}$ & 0.00283 & $(0.326)$ \\
\hline$a_{2}$ & $0.138^{* *}$ & $(2.383)$ & $b_{2}$ & -0.182 & $(-1.831)$ & $c_{2}$ & 0.00221 & $(0.075)$ \\
\hline$a_{3}$ & -0.0546 & $(-0.868)$ & $b_{3}$ & $0.314^{* *}$ & $(2.251)$ & $c_{3}$ & 0.00257 & $(0.124)$ \\
\hline$a_{4}$ & 0.0136 & $(1.152)$ & $b_{4}$ & -0.688 & $(-0.181)$ & $c_{4}$ & $0.4312^{* *}$ & $(5.593)$ \\
\hline$a_{5}$ & 0.162 & $(0.419)$ & $b_{5}$ & $0.114^{* *}$ & $(2.190)$ & $c_{5}$ & $-0.398^{* * *}$ & $(-2.998)$ \\
\hline$a_{6}$ & -0.0184 & $(-1.289)$ & $b_{6}$ & $-0.638^{* *}$ & $(-2.015)$ & $c_{6}$ & $0.632^{* *}$ & $(2.276)$ \\
\hline$a_{7}$ & $-0.472^{* * *}$ & $(-3.208)$ & $b_{7}$ & $0.672^{* * *}$ & (2.703) & $c_{7}$ & $0.910^{* * *}$ & $(2.863)$ \\
\hline$a_{8}$ & 0.0582 & $(0.602)$ & $b_{8}$ & $-0.710^{* *}$ & $(-2.310)$ & $c_{8}$ & $-0.238^{* * *}$ & $(-5.406)$ \\
\hline$a_{9}$ & -0.0695 & $(-0.168)$ & $b_{9}$ & 0.758 & $(0.258)$ & $c_{9}$ & -0.812 & $(-1.269)$ \\
\hline$\gamma_{h}$ & $18.454^{* * *}$ & $(2.672)$ & $\gamma_{s}$ & $127.626^{* * *}$ & $(3.815)$ & $\gamma_{r}$ & $69.661^{* * *}$ & $(2.912)$ \\
\hline$c_{h}$ & $0.0218^{* * *}$ & $(2.097)$ & $c_{s}$ & $0.00618^{* * *}$ & $(3.128)$ & $c_{r}$ & $0.338^{* *}$ & $(2.117)$ \\
\hline \multicolumn{9}{|c|}{ Panel B. Conditional variance equation } \\
\hline$c_{11}$ & $0.014^{*}$ & $(1.345)$ & $c_{22}$ & 0.014 & $(1.345)$ & $c_{33}$ & 0.024 & $(1.441)$ \\
\hline$a_{11}$ & $0.221^{* * *}$ & $(2.810)$ & $a_{22}$ & $0.280^{* *}$ & $(3.112)$ & $a_{33}$ & $0.632^{* * *}$ & $(3.115)$ \\
\hline$b_{11}$ & $0.632^{* * *}$ & $(3.214)$ & $b_{22}$ & $0.645^{* * *}$ & $(2.615)$ & $b_{33}$ & $0.264^{* * *}$ & $(2.715)$ \\
\hline$f_{1}$ & $0.121^{* *}$ & (1.983) & $f_{3}$ & $0.205^{* * *}$ & $(2.454)$ & $f_{5}$ & $0.116^{* *}$ & $(1.925)$ \\
\hline$f_{2}$ & $0.015^{*}$ & $(1.835)$ & $f_{4}$ & 0.018 & $(1.465)$ & $f_{6}$ & $0.038^{* * *}$ & $(2.031)$ \\
\hline \multicolumn{9}{|c|}{ Panel C. Conditional covariance equation } \\
\hline$c_{12}$ & 0.231 & $(1.412)$ & $c_{23}$ & 0.315 & $(1.732)$ & $c_{13}$ & $0.446^{* *}$ & (1.997) \\
\hline$a_{12}$ & $0.672^{* * *}$ & $(2.054)$ & $a_{23}$ & $0.627^{* * *}$ & (2.915) & $a_{13}$ & $0.682^{* *}$ & (3.196) \\
\hline$\alpha$ & $0.232^{* * *}$ & (3.154) & $b_{23}$ & $0.292^{* * *}$ & $(2.182)$ & $b_{13}$ & $0.291^{* * *}$ & (2.463) \\
\hline \multicolumn{9}{|c|}{ Panel D. Serious correlation test on standardized residuals } \\
\hline
\end{tabular}

\begin{tabular}{|c|c|c|c|c|c|c|c|c|}
\hline \multicolumn{3}{|c|}{$Z_{h}=\varepsilon_{h t} / \sqrt{h n, t}$} & \multicolumn{3}{|c|}{$Z_{s}=\varepsilon_{s t} / \sqrt{h s, t}$} & \multicolumn{3}{|c|}{$Z_{r}=\varepsilon_{r t} / \sqrt{h r, t}$} \\
\hline $\begin{array}{l}\text { Series } \\
\text { correlation }\end{array}$ & $Z$-statistics & $P$-value & $\begin{array}{l}\text { Series } \\
\text { correlation }\end{array}$ & $Z$-statistics & $P$-value & $\begin{array}{l}\text { Series } \\
\text { correlation }\end{array}$ & $Z$-statistics & $P$-value \\
\hline$Q(12)$ & 12.361 & 0.914 & $Q(12)$ & 9.936 & 0.512 & $Q(12)$ & 2.886 & 0.156 \\
\hline \multicolumn{9}{|c|}{ D2. Square of standardized residuals } \\
\hline \multicolumn{3}{|l|}{$Z_{h}^{2}$} & \multicolumn{3}{|l|}{$Z_{s}^{2}$} & \multicolumn{3}{|l|}{$Z_{r}^{2}$} \\
\hline $\begin{array}{l}\text { Series } \\
\text { correlation }\end{array}$ & $Z$-statistics & $P$-value & $\begin{array}{l}\text { Series } \\
\text { correlation }\end{array}$ & $Z$-statistics & $P$-value & $\begin{array}{l}\text { Series } \\
\text { correlation }\end{array}$ & $Z$-statistics & $P$-value \\
\hline$Q^{2}(12)$ & 9.452 & 0.914 & $Q^{2}(12)$ & 12.361 & 0.712 & $Q^{2}(12)$ & 0.162 & 0.945 \\
\hline \multicolumn{9}{|c|}{ D3. Interaction of standardized residuals } \\
\hline \multicolumn{3}{|l|}{$Z_{h} Z_{s}$} & \multicolumn{3}{|l|}{$Z_{h} Z_{r}$} & \multicolumn{3}{|l|}{$Z_{s} Z_{r}$} \\
\hline $\begin{array}{l}\text { Series } \\
\text { correlation }\end{array}$ & $Z$-statistics & $P$-value & $\begin{array}{l}\text { Series } \\
\text { correlation }\end{array}$ & $Z$-statistics & $P$-value & $\begin{array}{l}\text { Series } \\
\text { correlation }\end{array}$ & $Z$-statistics & $P$-value \\
\hline$Q(12)$ & 8.715 & 0.445 & $Q(12)$ & 10.361 & 0.582 & $Q(12)$ & 9.662 & 0.825 \\
\hline
\end{tabular}

Note: Author's calculation; *, **, *** statistically significant at level of $10 \%, 5 \%$, and $1 \%$, respectively. 
As shown in Panel A of Table 9, the effect of stock prices with 1 lag on current stock prices has an estimated coefficient of $0.314\left(=b_{3}\right)$, whereas the estimated coefficient of smooth transition is $127.626\left(=\gamma_{s}\right)$, which is the largest compared with house prices and interest rates. This result suggests that stock prices show rapid speed of transit from one state to another while deviating from the long-run equilibrium. Regarding the estimated coefficient of threshold effect for stock prices with the value of $0.00618\left(=c_{s}\right)$, this indicates the stock market price will diverge the long-run equilibrium by $0.6 \%$ for smooth transition, suggesting that stock prices are frequently transformed among different states. Once the change in house price transits, the lag effect with a negative value of $-0.182\left(=b_{2}\right)$ changes to a positive effect with value of $0.854\left(=b_{2}+b_{7}\right)$, implying that a positive effect $\left(0.314=b_{3}\right)$ exists in long run equilibrium, but a negative effect $\left(-0.402=b_{3}+b_{8}\right)$ exists in disequilibrium in the long run.

Based on the results from Panel A of Table 9, interest rates are not affected by other variables. The estimated coefficient of smooth transition is $69.661\left(=\gamma_{r}\right)$; this suggests that straying from the long-run equilibrium interest rate would transform the state at a higher speed than the housing price but at a slower speed than the stock price. According to the threshold coefficient of the interest rate of $0.338\left(=c_{r}\right)$, the interest rates start to adjust in a nonlinear smooth transition when deviating from the long-run equilibrium at $33.8 \%$. After the interest rate experiences a state transition, the original positive effect $\left(0.00221=c_{2}\right)$ of house prices maintains the same effect $(0.912=$ $c_{2}+c_{7}$ ); however, the original positive effect of the stock price $\left(0.00257=c_{3}\right)$ changes to a negative influence $\left(-0.235=c_{3}+c_{8}\right)$.

Moreover, the causality among house price, stock market prices and interest rate indicates that, prior to a state transition, there is no interrelation among the series; however, after the state transition, house prices will lead stock prices and either house prices or stock prices will lead interest rates. Finally, the estimated coefficients of smooth transition for house prices, stock market prices and interest rates are $18.454\left(=\theta_{s}\right), 127.626\left(=\gamma_{s}\right)$, and $69.661\left(=\gamma_{r}\right)$, respectively. This means that the stock market price transforms the state at the fastest speed compared to the others while diverging the long-term equilibrium. Additionally, the estimated coefficients of the threshold values for house prices, stock market prices and interest rates are $0.0218\left(=c_{h}\right), 0.00618\left(=c_{s}\right)$, and $0.338\left(=c_{r}\right)$, respectively. This implies that stock prices would transform their state while slightly deviating from the long-run equilibrium; however, interest rates proceed with state transitions while largely diverging in long-run equilibrium.

\section{Conditional variance equation in STVECM-GARCH}

Based on the results from panel B of Table 9, the stock price return and square of the error term with lag 1 has a significantly positive effect on the current stock price return $\left(0.645=b_{22}\right.$ and $0.280=$ $a_{22}$ ). The volatility of stock price return with lag 1 has a significantly positive effect on the current volatility of change in the interest rate $\left(0.038=f_{6}\right)$. This result implies investors must consider the historical performance of the stock price when investing in the capital market.

\section{Conditional covariance equation in STVECM-GARCH}

Panel C in Table 9 reports the results of the conditional covariance equations in the STVEC-GARCH model. The previous house prices and interest rates have significantly interactive effects on the covariance of stock prices and interest rates. According to Panel D of Table 9, the results of the estimated residuals series reveal that there is no series autocorrelation (in Panel D of D1 and D2) and heteroskedasticity (in Panel D of D3) in all series. This indicates that our empirical model has goodness of fit, and the analysis is effective and explanatory.

Rationally, if encountering an event or a shock, the change in one of these three variables will affect the other two variables to achieve a new equilibrium situation that transitions from the original regime to another regime. In general, this will occur through a smooth transition process after we have performed the test for a smooth transition effect on our series. We want to detect the nonlinear relations and volatility spillovers among house prices, stock market prices and interest rates.

\section{CONCLUSION REMARKS}

Using monthly data from January 1985 to March 2009, this paper builds a STAR-VECM model to empirically explore the dynamic adjustment process and nonlinear interrelationships among house prices, stock market prices and interest rates in Taiwan. Simultaneously, we also use a GARCH model to examine the volatility spillover effects among those series. 
Empirical evidence indicates that the STVECGARCH model provides the best forecast ability with goodness of fit, and there are nonlinear and co-integrated relations among house prices, stock market prices and interest rates. Specifically, we indicate that the stock market price transforms the state at the fastest speed compared to the others, as they diverge in long-run equilibrium. This indicates that house prices would transit to another state while diverging from the equilibrium in the long run. The volatility of the stock price return with lag 1 has a significantly positive effect on the current volatility of the change in the interest rate. This result implies investors must consider the historical performance of the stock price when investing in the capital market. The previous house prices and interest rates have significantly interactive effects on the covariance of stock prices and interest rates.

\section{REFERENCES}

Akaike, H. 1969. Fitting autoregressive models for prediction, Annals of the Institute of Statistic Mathematics 21: 243-247. http://dx.doi.org/10.1007/ BF02532251

Attanasio, O.; Leicester, A.; Wakefield, M. 2011. Do house prices drive consumption growth? The coincident cycles of house prices and consumption in the UK, Journal of the European Economic Association 9: 399-435. http://dx.doi.org/10.1111/j.15424774.2011.01021.x

Bollerslev, T. 1986. Generalized autoregressive conditional heteroscedasticity, Journal of Financial Economics 31: 307-327.

Bollerslev, T.; Chou, R.Y.; Kroner, K. F. 1992. ARCH modeling in France: a review of the theory and empirical evidence, Journal of Econometrics 526: 5-59. http://dx.doi.org/10.1016/0304-4076(92)90064-X

Bollerslev, T.; Engle, R. F.; Wooldridge, J. M. 1998. A capital asset pricing model with time-varying covariances, Journal of Political Economy 96: 116-131. http://dx.doi.org/10.1086/261527

Calza, A.; Monacelli, T.; Stracca, L. 2013. Housing finance and monetary policy, Journal of the European Economic Association 11: 101-122. http://dx.doi. org/10.1111/j.1542-4774.2012.01095.x

Case, B.; Goetzmann, W. N.; Rouwenhorst, K. G. 2000. Global real estate markets - cycles and fundamentals, NBER Working Paper No. 7566. http://dx.doi. org/10.3386/w7566

Case, K.; Shiller, R.; Quigley, J. 2005. Comparing wealth effects: the stock market versus the housing market, Advances in Macroeconomics 5: 1-32. http://dx.doi. org/10.2202/1534-6013.1235

Chan, F.; McAleer, M. 2003. Estimating smooth transition autoregressive models with GARCH errors in the presence of extreme observations and outliers, Applied Financial Economics 13: 581-592. http://dx.doi.org/10.1080/0960310022000029295

Chen, N. K.; Chen, S. S.; Chou, Y. H. 2010. House prices, collateral constraint, and the asymmetric effect on consumption, Journal of Housing Economics 19: 26-37. http://dx.doi.org/10.1016/j.jhe.2009.10.003

Chirinko, R. S.; de Haan, L.; Sterken, E. 2004. Asset price shocks, real expenditures, and financial structure: a multi-country analysis. DNB Working paper No. 14. De Nederlandsche Bank.

Dees, S.; Di Mauro, F.; Pesaran, M. H.; Smith, V. 2005. Exploring the international linkages of the Euro area: a global VAR analysis, CESifo working paper, No. 1425 .

Dickey, D. A.; Fuller, W. A. 1979. Distribution of the estimators for autoregressive time series with a unit root, Journal of American Statistic Association 74: $427-431$.

Dickey, D. A.; Fuller, W. A. 1981. Likelihood ratio statistics for autoregressive time series with a unit root, Econometrica 45: 1057-1072. http://dx.doi. org/10.2307/1912517

Dolde, W.; Tirtiroglu, D. 2002. Housing price volatility changes and their effects, Real Estate Economics 30: 41-66. http://dx.doi.org/10.1111/1540-6229.00029

Engle, R. F. 1982. Autoregressive conditional heteroskedasticity with estimates of the variance of U.K. inflation, Econometrica 50: 987-1008. http://dx.doi. org/10.2307/1912773

Engle, R. F.; Granger, C. W. J. 1987. Co-integration and error-correction: representation, estimation, and testing, Econometrica 55: 251-276. http://dx.doi. org/10.2307/1913236

Fu, Y.; Leung, W. K.; Lo, W. C. 1993. The dynamics of residential property markets and the stock market in Hong Kong, Technical report, No. 94-3. Asia-Pacific Financial and Forecasting Research Center.

Ghent, A. C.; Owyang, M. T. 2010. Is housing the business cycle? Evidence from US cities, Journal of Urban Economics 67: 336-351. http://dx.doi.org/10.1016/j. jue.2009.11.001

Goodhart, C.; Hofmann, B. 2008. House prices, money, credit, and the macroeconomy, Oxford Review of Economic Policy 24: 180-205. http://dx.doi.org/10.1093/ oxrep/grn009

Granger, C. W. J.; Swanson, N. 1996. Future developments in the study of cointegrated variables, Oxford Bulletin of Economics and Statistics 58: 537-553. http://dx.doi.org/10.1111/j.1468-0084.1996. mp58003007.x

Granger, C. W. J.; Terasvirta, T. 1993. Modeling nonlinear economic relationships. Oxford University Press.

Hirata, H.; Kose, M. A.; Otrok C.; Terrones, M. E. 2013. Global house price fluctuations: synchronization and determinants, NBER Working Paper No. 18362.

Hoesli, M.; Reka, K. 2015. Contagion channels between real estate and financial markets, Real Estate Economics 43: 101-138. http://dx.doi.org/10.1111/15406229.12070 
Hui, E. C. M.; Chan, K. K. K. 2013. Contagion across real estate and equity markets during European sovereign debt crisis, International Journal of Strategic Property Management 17: 305-316. http://dx.doi.org/ 10.3846/1648715X.2013.822837

Iacoviello, M. 2005. House prices, borrowing constraints, and monetary policy in the business cycle, American Economic Review 95: 739-764. http://dx.doi. org/10.1257/0002828054201477

Iacoviello, M.; Neri, S. 2010. Housing market spillovers: evidence from an estimated DSGE model, American Economic Review 2: 125-164. http://dx.doi. org/10.1257/mac.2.2.125

Jarocinski, M.; Smets, F. 2008. House prices and the stance of monetary policy, Federal Reserve Bank of St. Louis Review 90: 339-365.

Johansen, S. 1988. Statistical analysis of co-integration vectors, Journal of Economic Dynamics and Control 12: 231-254. http://dx.doi.org/10.1016/01651889(88)90041-3

Johansen, S.; Juselius, K. 1990. Maximum likelihood estimation and inference on co-integration with application to the demand for money, Oxford Bulletin of Economics and Statistics 52: 169-210. http://dx.doi. org/10.1111/j.1468-0084.1990.mp52002003.x

Leamer, E. 2007. Housing is the business cycle, NBER Working Paper No. 13428. http://dx.doi.org/10.3386/ w13428

Louis, H.; Sun, A. X. 2013. Long-term growth in housing prices and stock returns, Real Estate Economics 41: 663-708. http://dx.doi.org/10.1111/reec.12008

Luukkonen, R.; Saikkonen, P.; Terasvirta, T. 1988. Testing linearity against smooth transition autoregressive models, Biometrika 75: 491-499. http://dx.doi. org/10.1093/biomet/75.3.491

McMillan, D. G. 2005. Smooth-transition error-correction in exchange rates, North American Journal of
Economics and Finance 16: 217-232. http://dx.doi. org/10.1016/j.najef.2003.09.001

Musso, A.; Neri, S.; Stracca, L. 2011. Housing, consumption and monetary policy: how different are the US and the Euro area?, Journal of Banking and Finance 35: 3019-3041. http://dx.doi.org/10.1016/j.jbankfin.2011.04.004

Pavlidis, E.; Paya, I.; Peel, D.; Spiru, A. M. 2009. Bubbles in house prices and their impact on consumption: evidence for the US, Working Paper 2009/025, Department of Economics Lancaster University.

Rothman, P.; Van Dijk, D.; Franses, P. H. 2001. A multivariate STAR analysis of the relationship between money and output, Macroeconomic Dynamics 5: 506-532.

Schwert, G. W. 1989. Why does stock market volatility, change over time?, Journal of Finance 44: 11151154. http://dx.doi.org/10.1111/j.1540-6261.1989. tb02647.x

Sing, T. F.; Tan, Z. Y. 2013. Time-varying correlations between stock and direct real estate returns, Journal of Property Investment \& Finance 31: 179-195. http://dx.doi.org/10.1108/14635781311302591

Terasvirta, T. 1994. Specification, estimation, and evaluation of smooth transition autoregressive models, Journal of the American Statistical Association 89: 208-218.

Terasvirta, T.; Anderson, H. M. 1992. Characterizing nonlinear in business cycles using smooth transition autoregressive models, Journal of Applied Econometrics 7: 119-136. http://dx.doi.org/10.1002/ jae.3950070509

Tse, R. Y. C. 2001. Impact of property prices on stock prices in Hong Kong, Review of Pacific Basin Financial Markets and Policies 4: 29-43. http://dx.doi. org/10.1142/S0219091501000309 